\title{
Trace elements and radioactivity measurements in some terrestrial food crops in Jos-plateau, north central, Nigeria
}

\author{
N.N. JIBIRI ${ }^{1}$, J.C. AGOMUO ${ }^{1}$
}

(Manuscript received 12 July 2006, accepted 27 October 2006)

ABSTRACT Some crops of important nutritive requirements have been collected from farmlands located in Bitsichi an old tin mining town in north central region of Nigeria. The food crops were analyzed in order to determine trace element concentrations level using Neutron Activation Analysis (NAA). The activity concentrations due to natural radionuclides in the food samples and soil samples collected within the root zone of the crops were also determined using gamma-ray spectrometry (GRS). The NAA results obtained showed higher concentration of Potassium among the essential elements in all the crops. Calcium concentration in both maize and Guinea corn was below detection limit and also $\mathrm{Zn}$ in Green beans, sweet potato and cassava. The trace elements; Sc, $\mathrm{Hf}, \mathrm{Sm}$, and Th, were below detection limit in all the crops except in Green beans. Rubidium (Rb) and lanthanum (La) were below detection limits only in Cabbage. The activity concentrations of the natural radionuclides in the food samples were found to vary between 83 and $129 \mathrm{~Bq} \mathrm{~kg}^{-1}$ for ${ }^{40} \mathrm{~K}, 19$ and $30 \mathrm{~Bq} \mathrm{~kg}^{-1}$ for ${ }^{226} \mathrm{Ra}$ and 27 to $41 \mathrm{~Bq} \mathrm{~kg}{ }^{-1}$ for ${ }^{232} \mathrm{Th}$. In the soil samples the activity concentrations varied between 177 and $271 \mathrm{~Bq} \mathrm{~kg}^{-1}$ for ${ }^{40} \mathrm{~K}, 53$ and $96 \mathrm{~Bq} \mathrm{~kg}^{-1}$ for ${ }^{226} \mathrm{Ra}$ and 73 to $176 \mathrm{~Bq} \mathrm{~kg}^{-1}$ for ${ }^{232} \mathrm{Th}$. Results of activity concentration levels of the radionuclides obtained in similar crops collected for control measurements were found to be very low compared to those from the study area. The effective dose due to intake of the food crops considered in the study area was estimated based on the measured activity concentrations of ${ }^{226} \mathrm{Ra}$ and ${ }^{232} \mathrm{Th}$ in the food crops. It was found to vary between $0.01 \mathrm{mSv} \mathrm{y}^{-1}$ (Acha) and $1.35 \mathrm{mSv} \mathrm{y}^{-1}$ (Cassava) with a cumulative total dose estimated as $2.5 \mathrm{mSv}^{-1}$. The mining activities in the area are seen to have influenced the concentration of these trace elements and radionuclides in the food crops. However, they are seen not to pose any serious internal health burden due to ingestion given the realities of food choice by individuals in the study area.

Keywords: food crops / trace elements / radioactivity / ingestion dose / Jos-plateau / Nigeria

RÉSUMÉ Éléments traces et mesures de la radioactivité dans quelques récoltes vivrières terrestres du plateau de Jos dans le centre-nord du Nigéria.

Quelques récoltes d'aliments importants ont été effectuées dans des champs situés à Bitsichi, une ville minière d'étain dans la région nord central du Nigéria. Les récoltes vivrières ont été analysées afin de déterminer le niveau de concentration d'oligoélément en utilisant l'analyse par activation neutronique (AAN). Les concentrations de radioactivité des radionucléides naturels dans les échantillons alimentaires et des échantillons de sol rassemblés dans la zone des récoltes ont été également déterminées par spectrométrie gamma (GRS). Les résultats d'activation neutronique ont montré que la concentration la plus élevée parmi les éléments

\footnotetext{
1 Radiation and Health Research Physics Laboratory, Department of Physics, University of Ibadan, Oyo State, Nigeria.
} 


\begin{abstract}
essentiels dans toutes les récoltes était celle du potassium. La concentration en calcium dans le maïs et le maïs de Guinée était au-dessous de limite de détection comme celle du $\mathrm{Zn}$ dans les haricots verts, la patate douce et le manioc. Les éléments traces ; Sc, Hf, Sm et Th, étaient au-dessous de limite de détection dans toutes les récoltes excepté dans les haricots verts. Le rubidium (Rb) et le lanthane (La) étaient au-dessous des limites de détection seulement dans le chou. Les concentrations en activité des radionucléides naturels dans les échantillons alimentaires sont comprises entre 83 et $129 \mathrm{~Bq} \mathrm{~kg}^{-1}$ pour ${ }^{40} \mathrm{~K}, 19$ et $30 \mathrm{~Bq} \mathrm{~kg}^{-1}$ pour ${ }^{226} \mathrm{Ra}$ et 27 à $41 \mathrm{~Bq} \mathrm{~kg}^{-1}$ pour le ${ }^{232} \mathrm{Th}$. Dans les échantillons de sol, les concentrations d'activité varient entre 177 et $271 \mathrm{~Bq} \mathrm{~kg}^{-1}$ pour ${ }^{40} \mathrm{~K}, 53$ et $96 \mathrm{~Bq} \mathrm{~kg}^{-1}$ pour ${ }^{226} \mathrm{Ra}_{\text {et }} 73$ à $176 \mathrm{~Bq} \mathrm{~kg}^{-1}$ pour $^{232} \mathrm{Th}$. Les niveaux de radioactivité des radionucléides des récoltes dans une zone témoin sont beaucoup plus bas comparés à ceux de la zone d'étude. La dose efficace due à l'ingestion des récoltes vivrières considérées dans la zone d'étude a été estimée sur la base des concentrations en activité de ${ }^{226} \mathrm{Ra}$ et du ${ }^{232} \mathrm{Th}$. Elle est évaluée entre $0,01 \mathrm{mSv} \mathrm{y}^{-1}$ (Acha) et $1,35 \mathrm{de} \mathrm{mSv} \mathrm{y}^{-1}$ (manioc) pour une dose totale cumulative estimée en tant que $2,5 \mathrm{mSv}^{-1}$. L'extraction minière dans la zone a influencé la concentration de ces éléments traces et des radionucléides dans les récoltes vivrières. Cependant, elles ne posent pas de problème sérieux de santé lié à l'ingestion de ces récoltes guidées par les réalités locales dans le choix de la nourriture par les habitants de cette zone d'étude.
\end{abstract}

\title{
1. Introduction
}

The Jos area is located on a granite plateau about $1100 \mathrm{~m}$ above sea level in the north central part of Nigeria (Badejoko, 1975). Jos Plateau is known for mining and milling of tin and columbite. The geological formation and mineral distribution of the Jos-plateau is shown in Figure 1. The mining operation in this area started around 1904 . This activity disturbed about $320 \mathrm{~km}^{2}$ of cultivable land much of which was needed for food production because of the growing population (Alexander and Kidd, 2000). This operation involves physical excavation of soil with heavy machineries which gave rise to different heaps of laterite and ditches in these areas. Though the mining operation in large quantity has ceased, due to low market value as the country presently earns less than $0.5 \%$ of its foreign exchange from tin, local mining of tin which involves digging of pits and trenches is still going on in some areas (Alexander, 1996; Pasquini and Alexander, 2005). Some of the areas that were affected by these mining operations include: Bukuru, Bitsichi, Gana Ropp, Dorowa-Babuje, Dorowa Tsoho etc., but the large scale mining activities took place in Bitsichi in Barkin Ladi local government council of Jos Plateau. The radioactive nature of tin ore and its tailings was only realized in 1974, but before then, the tailings were treated as non-radioactive and were used for building construction and agricultural purposes (Babalola, 1984). The source of this high radioactivity has been the subject of many scientific investigations over the years and now it has been established that the by-products of mining and milling were very high in thorium than uranium content (Babalola, 1984; Oresegun and Babalola, 1990; Farai and Sanni, 1992; Oresegun and Babalola, 1993). Due to the level of ecological devastation and non restorative measures 


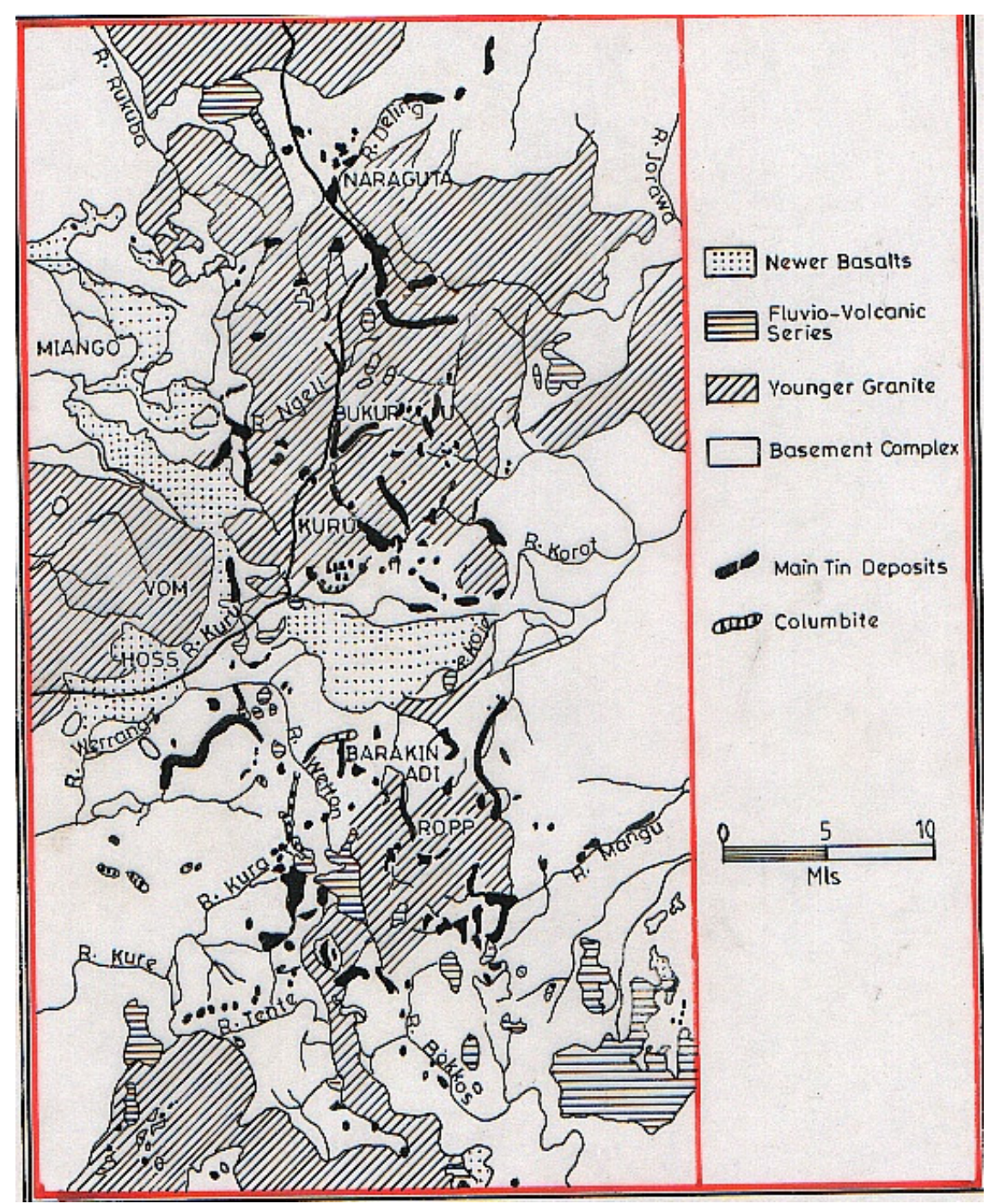

Figure 1 - The geological formations and mineral distributions of Jos-plateau, Nigeria.

Les formations géologiques et les distributions minérales du plateau de Jos au Nigéria.

such as reclamation approaches by constituted authorities this area has attracted the attention of environmentalist especially in Bitsichi (Alexander and Kidd, 2000). In this area, farmers complained of low farm produce yield as compared to areas where mining did not take place an indication that suggest that the operations 
may have affected the soil integrity on which crops are eventually grown due to food security and economic pressures. However, not much has been done to ascertain the concentration of the trace elements and natural radionuclides in the food crops grown in these areas following the level of reported scientific studies above.

The concentration or quantity of nutritive elements in crop depends on the soil on which the crop is grown. One essential feature of soil is the ability to retain and accumulate for long time elements and radionuclides coming from the outside. Therefore, for years, a contaminated soil becomes a source through which radionuclides, trace elements and heavy metals enter agricultural products and subsequently enter the food chain from the soil by plant root uptake (Mc Donald et al., 1999; Breuninger et al., 2002; Hernandez et al., 2004). The long established tin mining operation in Jos plateau may have directly or indirectly affected the concentration of trace elements, heavy metal and radionuclide in food crops planted around these areas. In addition to high level of external ionizing radiation, individuals living in high background radiation areas can be exposed internally especially through the intake of foodstuffs. It has therefore become imperative to assess the radiological implication due to consumption of different food crops in the area with the following objectives to:

(1) determine the trace element concentrations level in the food crops using neutron activation analysis (NAA);

(2) determine the activity concentrations due to ${ }^{40} \mathrm{~K},{ }^{226} \mathrm{Ra}$ and ${ }^{232} \mathrm{Th}$ in the food and soil samples by gamma-ray spectrometry;

(3) deduce the intake dose due to the different radionuclides in the food crops.

\section{Materials and methods}

\subsection{Sampling}

Samples of cassava (Manihot esculenta), guinea corn (Sorghum bicolor L), acha (hungry rice) (Digitaria exillis stapf), cabbage (Brassica oleracea capitata), maize (Zea mays), sweet potatoes (Ipomoea batatas) and green beans (Phaseolus vulgaris) were collected directly from some farm lands around the old mining sites in Bitsichi town to ensure that they are site specific samples. Soil samples were equally collected from the spots where the food samples were taken. Effort was made to ensure that at least two samples each of these food crops were collected across the farmlands, since it was not possible to have a farmland where all the crops are grown. The sample size, however, was considered reasonably well enough for the purpose of the study. The map of Jos plateau showing the location of the sampling site is shown in Figure 2. All the food samples were washed and 


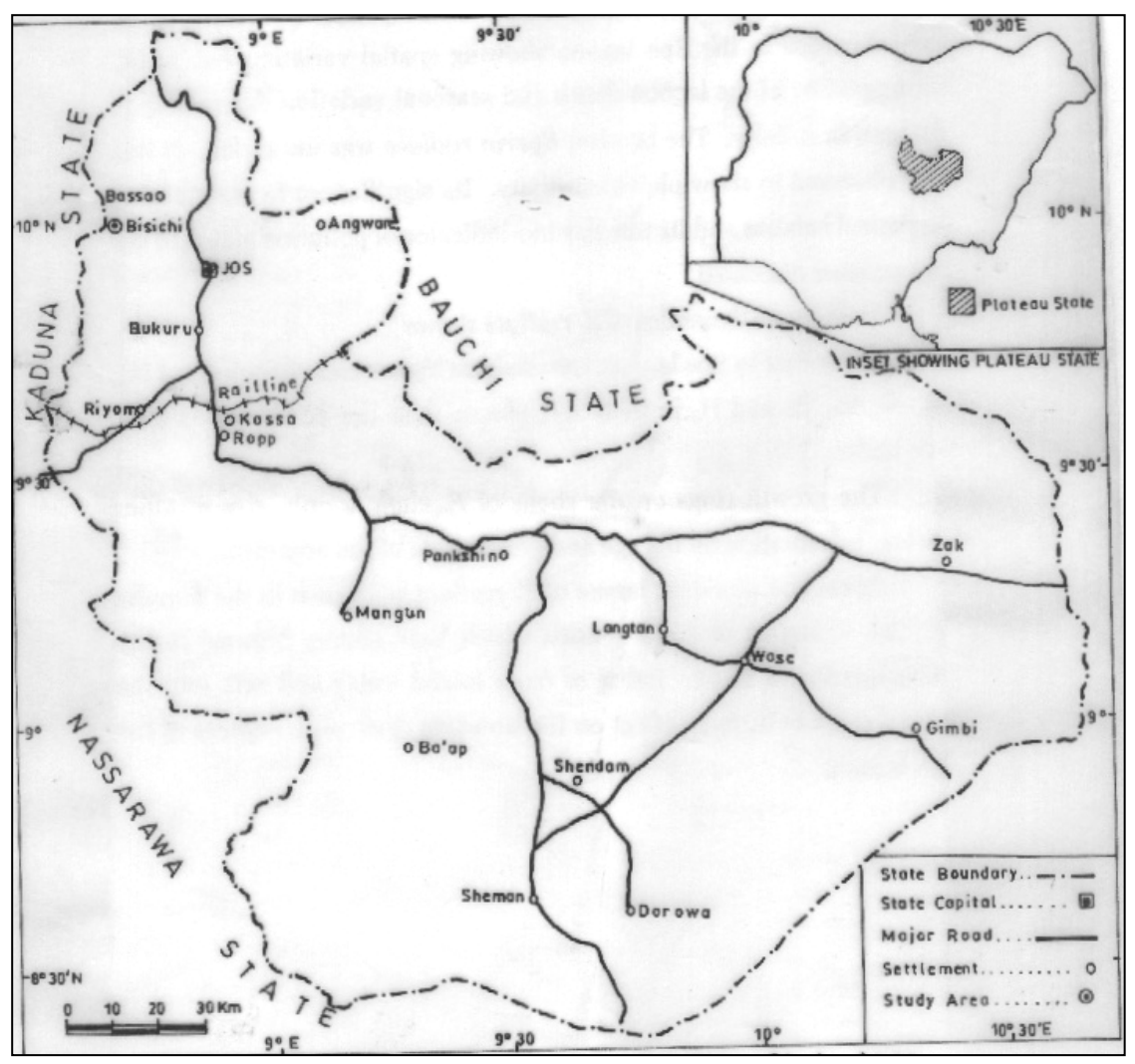

Figure 2 - The map of Jos-plateau showing the location of the sampling site.

Carte du plateau de Jos montrant l'emplacement du site de prélèvement.

the non-edible parts removed. They were oven dried at a temperature of about $70{ }^{\circ} \mathrm{C}$ until they reached a constant weight. They were then grounded properly in a wooden mortar for homogenization. The soil samples were also oven dried at a temperature of about $100{ }^{\circ} \mathrm{C}$ until they reached a constant weight.

\subsection{Sample preparation and encapsulation for NAA}

The samples were grounded and sieved with a $300 \mu \mathrm{m}$ sieve. About $200 \mathrm{mg}$ of each of the food samples was measured and encapsulated. The encapsulation material used in this work is polyethylene. For quality assurance, before encapsulation the polyethylene and the rabbit capsules used during encapsulation were cleaned by soaking in 1:1 $\mathrm{HNO}_{3}$ for three days and washed with de-ionized water and then 
dried in the oven for about $2-3 \mathrm{~h}$ at $50{ }^{\circ} \mathrm{C}$. A blank count was carried out on the polyethylene and rabbit capsules to ensure no contamination and none of the element of interest was detected (in other words they were below the limit of detection).

\subsection{Sample preparation for radioactivity measurement}

After crushing, the samples (both food and soil samples ) were weighed and sealed in plastic containers $(8 \mathrm{~cm} \times 6 \mathrm{~cm})$ and kept for at least one month to allow for the secular equilibrium of ${ }^{222} \mathrm{Rn}$ and its progeny with ${ }^{226} \mathrm{Ra}$. Before the sealing, the containers were washed, dried and certified to be non-radioactive.

\subsection{Analytical procedure}

\subsubsection{Neutron activation analysis (NAA)}

The NAA analysis was carried out at the Center for Energy Research and Training (CERT) at Ahmadu Bello University, Zaria, Nigeria. The Nigerian Research Reactor-1 (NIRR-1) is a miniature Neutron Source reactor (MNSR) and has a tank in-pool structure configuration with nominal thermal power rating of $31 \mathrm{~kW}$. It is a low power nuclear reactor, which has highly enriched uranium as fuel, light water moderator and beryllium as reflector. The associated facility for radioactivity measurement is a gamma-ray data acquisition system comprising a horizontal dip-stick High-Purity Germanium (HPGe) detector with relative efficiency of $10 \%$ at $1332.5 \mathrm{keV}$ gamma-ray line, the MAESTRO emulation software compatible with the $\mathrm{ADCAM}^{\circledR}$ Multichannel analyzer (MCA) card, associated electronics modules all manufactured by EG\&G ORTEC and a personal computer. The efficiency curves of the detector system have been determined by standard gamma-ray sources in the energy range of 59.5-2 $254 \mathrm{keV}$. The certified reference biological materials IAEA-359 and IAEA-336 were used for the identification of gamma-ray product radionuclides through their energies and quantitative analysis of their concentrations. The gamma-ray spectrum analysis software WINSPAN 2004 was used for the data processing. For irradiation of the samples, two schemes were adopted based on the half-life of product radionuclides. Both schemes were adopted because we are interested in both the short-lived and the long-lived radionuclides. For the elements leading to shortlived activation products the samples were each packed and sealed in $7 \mathrm{~cm}^{3}$ rabbit capsules and irradiated each for about $2 \mathrm{~min}$ in turn in an outer irradiation channel B4 where the neutron spectrum is 'soft'. For elements leading to long-lived activation products, samples wrapped in polyethylene films were packed and sealed in a stack inside the $7 \mathrm{~cm}^{3}$ rabbit capsules and irradiated for $6 \mathrm{~h}$ in any of 
the small inner irradiation channels (A1, B1, B2, and B3) to take advantage of the maximum value of thermal neutron flux in the inner channels. After irradiation, radioactivity measurement of induced radionuclides is performed by the PC based gamma-ray spectrometry set up. Following the short regime the first round of counting was performed for $10 \mathrm{~min}$ (S1) after waiting for 2-15 min. Samples were placed in a Plexiglas sample holder designated as ' $\mathrm{H} 2$ ' which corresponds to source-detector geometry of $5 \mathrm{~cm}$. The second round of counting was also carried out for $10 \mathrm{~min}$ following short irradiation regime (S2) after waiting period of 3-4 h. Samples were counted on a Plexiglas holder designated as 'H1' corresponding to source-detector geometry of $1 \mathrm{~cm}$. Usually, the neutron flux for short irradiation regime S1 and S2 is $10^{11} \mathrm{n} / \mathrm{cm}^{2} \mathrm{~s}$ but for this work (being biological samples) the neutron flux was raised to $5 \times 10^{11} \mathrm{n} / \mathrm{cm}^{2} \mathrm{~s}$ in order to increase the detection sensitivity for analysis of elements using procedures $\mathrm{S} 1$ and S2. For long irradiation regime, the first round of counting was carried out for 30 min, following long irradiation (L1) using holder ' $\mathrm{H} 1$ ' after a waiting time of 4-5 days. The second round of counting was performed for $60 \mathrm{~min}$ (L2) after waiting (cooling) time of $10-15$ days.

\subsubsection{Radioactivity analytical procedure}

The natural radionuclide concentration in the soil and food samples was carried out in this work using gamma-ray spectrometry. This system consist of a 3" $\times 3$ " NaI (Tl) detector well shielded in a $6 \mathrm{~cm}$ lead shield, the MAESTRO emulation software compatible with ADCAM $^{\circledR}$ Multichannel analyzer (MCA) card, associated electronics modules (amplifier and power supply modules) all made by EG\&G ORTEC and personal computer. The detector has a resolution of about $8 \%$ at $0.662 \mathrm{MeV}$ of ${ }^{137} \mathrm{Cs}$ which is capable of distinguishing the gamma ray energies used for the measurements. The photopeak at $1.460 \mathrm{MeV}$ was used for the measurement of ${ }^{40} \mathrm{~K}$ while those at $1.760 \mathrm{MeV}$ peak from ${ }^{214} \mathrm{Bi}$ and $2.614 \mathrm{MeV}$ from ${ }^{208} \mathrm{Tl}$ were used for the measurement of ${ }^{226} \mathrm{Ra}$ and ${ }^{232} \mathrm{Th}$, respectively. These peaks are clean, reasonably strong with very low continuum and were considered appropriate because of the poor resolution of the $\mathrm{NaI}(\mathrm{Tl})$ detector used in this work. Calibration of the detector system was achieved by determining its gamma ray counting efficiencies over the energy range 0.662 to $2.615 \mathrm{MeV}$ using a certified reference source soil sample traceable to source number $48722-356$ by Analytic Inc. Atlanta, Georgia. For the food samples the IAEA certified reference source traceable to source number IAEA-152 was used. The counting time of $8 \mathrm{~h}$ and $10 \mathrm{~h}$ were used respectively for the soil and food samples respectively. The net area count after background corrections in each photopeak was used in the computation of the activity concentration of each of the radionuclide in the food and soil samples using the MAESTRO emulation software. The activity 
concentrations of the radionuclides in the soil samples in $\mathrm{Bq} \mathrm{kg}^{-1}$ were calculated using the following equations (Jibiri and Ajao, 2005; Jibiri and Bankole, 2006):

$$
C\left(\mathrm{~Bq} \mathrm{~kg}^{-1}\right)=\frac{C_{k}}{A_{k}} A
$$

$C_{k}$ is the activity concentration of the radionuclide in the standard reference sample $\left(\mathrm{Bq} \mathrm{kg}{ }^{-1}\right), A$ is the net area count after background correction in the spectrum of the radionuclide in the sample and $A_{k}$ is the net area count after background correction under the spectrum of the radionuclide in the standard reference sample. The standard reference soil sample used was prepared from Rocketdyne Laboratories California; USA which is traceable to a mixed standard gamma source (Ref. No. 48722-356) by Analytic Inc. Atlanta, Georgia. A uniform mass of $200 \mathrm{~g}$ was used for the soil samples while for the food samples the mass used ranged between 80 and $200 \mathrm{~g}$. Due to the different mass used for the food samples the activity concentrations was obtained using the expression (Olomo, 1990; Akinloye and Olomo, 2000):

$$
C\left(\mathrm{~Bq} \mathrm{~kg}^{-1}\right)=\frac{C_{n}}{\varepsilon P_{\gamma} M_{s}}
$$

where $C$ is the activity concentration of the radionuclide in the sample, $C_{n}$ is the count rate under each photopeak due to each radionuclides, $\varepsilon$ is the detector efficiency of the specific $\gamma$-ray, $P_{\gamma}$ is the absolute transition probability of the specific $\gamma$-ray and $M_{s}$ is the mass of the sample $(\mathrm{kg})$.

\section{Results and discussion}

\subsection{Concentration levels}

Table I presents the results of the major and trace element analysis in the food samples while the results of the activity concentrations due to natural radionuclides in the soil and food crops are presented respectively in Tables II and III. As could be observed from Table III, radioactivity measurements on cabbage and green beans were not reported, this is due to the fact that the reasonable quantity of mass required for radioactivity measurements was not obtained after preparation. From Table I, potassium has higher concentration among the major elements in all the food crops. The highest potassium content of $30400 \pm 608 \mathrm{ppm}$ was obtained in cabbage while the lowest value of $6824 \pm 328 \mathrm{ppm}$ was obtained in sweet potato. Calcium concentration was below detection limit in both maize and Guinea corn; also was $\mathrm{Zn}$ in green beans, sweet potato and cassava. The real trace elements; Sc, $\mathrm{Hf}, \mathrm{Sm}$, and Th, were below detection limit in all the crops except in green beans. Rubidium $(\mathrm{Rb})$ and lanthanum ( $\mathrm{La}$ ) were below detection limits only in Cabbage. The crops with seeds such as beans and corn showed higher absorption of the trace 
TRACE ELEMENTS AND RADIOACTIVITY MEASUREMENTS

TABLE I

The analytical result of trace elements in the food crops.

Résultats analytiques des elements traces dans les récoltes vivrières.

\begin{tabular}{|c|c|c|c|c|c|c|}
\hline \multirow{2}{*}{ Elements } & \multicolumn{6}{|c|}{ Food crop types } \\
\hline & Green beans & Sweet potato & Cassava & Guinea corn & Maize & Cabbage \\
\hline $\mathrm{Na}(\mathrm{ppm})$ & $86.2 \pm 4.9$ & $766 \pm 18$ & $36.6 \pm 3.4$ & $67.0 \pm 4.6$ & $30.7 \pm 2.9$ & $794 \pm 18$ \\
\hline $\mathrm{K}(\mathrm{ppm})$ & $18310 \pm 458$ & $6824 \pm 328$ & $6938 \pm 278$ & $7930 \pm 293$ & $11590 \pm 406$ & $30400 \pm 608$ \\
\hline $\mathrm{Mg}(\mathrm{ppm})$ & $1668 \pm 458$ & $453 \pm 131$ & $478 \pm 94$ & $2879 \pm 127$ & $4603 \pm 180$ & $1754 \pm 163$ \\
\hline $\mathrm{Ca}(\mathrm{ppm})$ & $1922 \pm 242$ & $826 \pm 132$ & $602 \pm 122$ & BDL & BDL & $3828 \pm 306$ \\
\hline $\mathrm{Al}$ (ppm) & $785 \pm 10$ & $102 \pm 4$ & $181 \pm 6$ & $144 \pm 4$ & $228 \pm 6$ & $189 \pm 6$ \\
\hline $\mathrm{Zn}(\mathrm{ppm})$ & BDL & BDL & BDL & $75.0 \pm 17.8$ & $82.7 \pm 18.9$ & $88.4 \pm 18.8$ \\
\hline $\mathrm{Mn}(\mathrm{ppm})$ & $35.3 \pm 0.5$ & $17.5 \pm 0.4$ & $11.3 \pm 0.3$ & $25.5 \pm 0.4$ & $60.9 \pm 5.8$ & $57.2 \pm 0.6$ \\
\hline $\mathrm{Rb}(\mathrm{ppm})$ & $85.5 \pm 10.3$ & $44.3 \pm 10.1$ & 37.56 .7 & $41.7 \pm 8.5$ & $20.7 \pm 4.6$ & BDL \\
\hline Sc (ppm) & $0.17 \pm 0.03$ & BDL & BDL & BDL & BDL & BDL \\
\hline Hf (ppm) & $0.54 \pm 0.12$ & BDL & BDL & BDL & BDL & BDL \\
\hline $\mathrm{La}(\mathrm{ppm})$ & $1.21 \pm 0.09$ & $0.73 \pm 0.13$ & $0.57 \pm 0.07$ & $0.29 \pm 0.05$ & $0.38 \pm 0.06$ & BDL \\
\hline $\mathrm{Sm}(\mathrm{ppm})$ & $0.17 \pm 0.01$ & BDL & BDL & BDL & BDL & BDL \\
\hline Th (ppm) & $1.10 \pm 0.17$ & BDL & BDL & BDL & BDL & BDL \\
\hline $\mathrm{Cl}(\mathrm{ppm})$ & $882 \pm 36$ & $2184 \pm 57$ & $337 \pm 22$ & $317 \pm 20$ & $874 \pm 34$ & $1943 \pm 53$ \\
\hline $\mathrm{Br}(\mathrm{ppm})$ & $1.29 \pm 0.11$ & $1.18 \pm 0.18$ & $0.62 \pm 0.09$ & $0.660 \pm .12$ & $0.32 \pm 0.07$ & $0.98 \pm 0.17$ \\
\hline
\end{tabular}

BDL - Below detection limit. \pm indicates uncertainty from counting statistics.

TABLE II

The activities of the radionuclide in soil samples.

Activité des radionucléides dans les échantillons de sol.

\begin{tabular}{lccc}
\hline $\begin{array}{l}\text { Activity concentration }\left(\mathrm{Bq} \mathrm{kg}^{-1}\right) \\
\text { Crop farms }\end{array}$ & ${ }^{40} \mathrm{~K}$ & ${ }^{226} \mathrm{Ra}$ & ${ }^{232} \mathrm{Th}$ \\
\hline Acha (Hungry rice) & $271 \pm 17$ & $96 \pm 16$ & $107 \pm 3$ \\
Cassava 1 & $287 \pm 17$ & $74 \pm 15$ & $177 \pm 6$ \\
Cassava 2 & $132 \pm 9$ & $65 \pm 14$ & $97 \pm 3$ \\
Guinea corn & $132 . \pm 8$ & $76 \pm 14$ & $73 \pm 3$ \\
Maize & $177 \pm 12$ & $53 \pm 12$ & $97 \pm 3$ \\
\hline
\end{tabular}

elements compared to tubercles such as potato and cassava. This observation has been similarly reported (Njafang et al., 2006). The activity concentrations of the natural radionuclides in the food samples was found to vary between $83 \mathrm{~Bq} \mathrm{~kg}^{-1}$ in sweet potato and $129 \mathrm{~Bq} \mathrm{~kg}^{-1}$ in cassava for ${ }^{40} \mathrm{~K}, 19 \mathrm{~Bq} \mathrm{~kg}^{-1}$ in cassava and $30 \mathrm{~Bq} \mathrm{~kg}^{-1}$ in acha for ${ }^{226} \mathrm{Ra}$ and $27 \mathrm{~Bq} \mathrm{~kg}^{-1}$ in acha and $41 \mathrm{~Bq} \mathrm{~kg}^{-1}$ in sweet potato 
TABLE III

The activities of the radionuclide in food samples and effective dose due to ingestion. Activité des radionucléides dans les échantillons alimentaires et dose efficace liée à l'ingestion.

\begin{tabular}{lcccc}
\hline \multicolumn{2}{l}{ Activity concentration $\left(\mathrm{Bq} \mathrm{kg}^{-1}\right)$} & & \\
Food samples & ${ }^{40} \mathrm{~K}$ & ${ }^{226} \mathrm{Ra}$ & ${ }^{232} \mathrm{Th}$ & $\begin{array}{c}\text { Annual Effective dose due } \\
\text { to ingestion }\left(\mathrm{mSv}^{-1}\right)\end{array}$ \\
\hline Acha & $87 \pm 6$ & $30 \pm 8$ & $27 \pm 1$ & 0.01 \\
Cassava & $129 \pm 9$ & $19 \pm 6$ & $29 \pm 1$ & 1.35 \\
Guinea corn & $87 \pm 6$ & $27 \pm 6$ & $27 \pm 1$ & 0.61 \\
Maize & $102 \pm 6$ & $19 \pm 6$ & $40 \pm 1$ & 0.29 \\
\hline Sweet potato & $83 \pm 6$ & $27 \pm 10$ & $41 \pm 2$ & 0.24 \\
\hline
\end{tabular}

for ${ }^{232} \mathrm{Th}$. The activity concentrations of ${ }^{40} \mathrm{~K},{ }^{226} \mathrm{Ra}$ and ${ }^{232} \mathrm{Th}$ in the food crops from this area were about 10 orders of magnitude higher than those obtained in other parts of the country. For instance in tuber products the radionuclide levels varied from 10.6 to $46.4 \mathrm{~Bq} \mathrm{~kg}^{-1}$ for ${ }^{40} \mathrm{~K}, 0.5$ to $2.7 \mathrm{~Bq} \mathrm{~kg}^{-1}$ for ${ }^{238} \mathrm{U}$ and from BDL $-1.4 \mathrm{~Bq} \mathrm{~kg}^{-1}$ for ${ }^{232} \mathrm{Th}$ (Akinloye and Olomo, 2000) while in cereal crops the values of the radionuclides varied from 36.4 to $186.9 \mathrm{~Bq} \mathrm{~kg}^{-1}$ for ${ }^{40} \mathrm{~K}, 0.2$ to $1.4 \mathrm{~Bq} \mathrm{~kg}^{-1}$ for ${ }^{238} \mathrm{U}$ and from 0.3 to $1.8 \mathrm{~Bq} \mathrm{~kg}^{-1}$ for ${ }^{232} \mathrm{Th}$ (Arogunjo, 2003). The ${ }^{40} \mathrm{~K}$ value of sweet potato in this study is also lower than that of the value $136 \pm$ $2 \mathrm{~Bq} \mathrm{~kg}^{-1}$ reported in Spain (Hernandez et al., 2004). Furthermore, samples of the food crops similar to the ones considered in the study were collected from Kaduna State for control radioactivity measurements. Kaduna State was chosen because it is located in the north central region of the country as the study area and it also has no history of tin mining activities. The natural environmental radioactivity levels in the State have been reported to be within the world average normal range (Farai and Jibiri, 2000). The result of the activity concentrations of the radionuclides in the food crops from Kaduna State (control site) is presented in Table IV. Results are lower than those from the study area. It is also envisaged that trace elements values will equally be lower in their concentration values. This therefore suggests that the mining activities may have influenced their levels in crops in the study area. Also fertilizer largely used to improve soil fertility is also seen to have enhanced the quantity of these radionuclides in the soil and consequently through uptake are made available to the plants. For the soil samples the activity concentrations varied between 177 and $271 \mathrm{~Bq} \mathrm{~kg}^{-1}$ for ${ }^{40} \mathrm{~K}, 53$ and $96 \mathrm{~Bq} \mathrm{~kg}^{-1}$ for ${ }^{226} \mathrm{Ra}$ and 73 to $176 \mathrm{~Bq} \mathrm{~kg}^{-1}$ for ${ }^{232} \mathrm{Th}$. In all the soil samples analyzed the concentration of ${ }^{232} \mathrm{Th}$ is higher than that of ${ }^{226} \mathrm{Ra}\left({ }^{238} \mathrm{U}\right)$. 
TABLE IV

The activities of the radionuclide in food samples (control site). Activités des radionucléides dans les aliments de la zone témoin.

\begin{tabular}{lccc}
\hline $\begin{array}{l}\text { Activity concentration }\left(\mathrm{Bq} \mathrm{kg}^{-1}\right) \\
\text { Food samples }\end{array}$ & ${ }^{40} \mathrm{~K}$ & ${ }^{226} \mathrm{Ra}$ & ${ }^{232} \mathrm{Th}$ \\
\hline Acha & $24 \pm 3$ & $6 \pm 1$ & $6 \pm 2$ \\
Cassava & $94 \pm 3$ & $2 \pm 1$ & $2 \pm 1$ \\
Sweet potato & $113 \pm 3$ & $\mathrm{BDL}$ & $7 \pm 2$ \\
Guinea corn & $38 \pm 2$ & $\mathrm{BDL}$ & $6 \pm 2$ \\
Maize & $38 \pm 3$ & $3 \pm 1$ & $5 \pm 2$ \\
Millet & $38 \pm 3$ & $3 \pm 1$ & $\mathrm{BDL}$ \\
\hline
\end{tabular}

\subsection{Effective dose from ingestion}

Radiation doses obtained due to the intake of food is calculated from the amount of radionuclide deposited on foodstuff, the activity concentration of a particular radionuclide in food per unit deposition, the consumption rate of the food products and the dose per unit activity ingested. Thus the effective dose due to the intake of these food crops can be calculated using the formula (Breuninger et al., 2002; RIFE, 2005):

$$
D_{i}=\left(U_{R a} C_{R a}+U_{T h} C_{T h}\right) \times W \times 10^{-3}
$$

where, $D_{i}=$ effective dose from intake of a particular food, $U_{R a}\left(0.28 \mu \mathrm{Sv} \mathrm{Bq}{ }^{-1}\right)$ and $U_{T h}\left(0.230 \mu \mathrm{Sv} \mathrm{Bq}^{-1}\right)$ are the dose per unit activity for ${ }^{226} \mathrm{Ra}$, and ${ }^{232} \mathrm{Th}$ respectively (ICRP 1996; RIFE, 2005), $C_{R a}$, and $C_{T h}$ are the activity concentration of ${ }^{226} \mathrm{Ra}$, and ${ }^{232} \mathrm{Th}$ respectively, $W$ is the consumption rate $\left(\mathrm{kg} \mathrm{y}^{-1}\right)$ and $10^{-3}$ is a factor that converts micro to milli. The indigenes of Bitsichi (the study area) fall within the Northern region of Nigeria where grains and tubers are staple food of nutritive importance (Olayemi, 1998; Maziya-Dixon et al., 2004). Presently, no site specific consumption data exist in the study area and as such we have adopted the country's mean annual consumption rate per capita values (Tab. V) to enable us calculate the effective dose due intake of the food stuffs using equation (3). Potassium-40 was not considered in the effective dose calculation in this study because as an isotope of an essential element, it is under homeostatic control depending on the physiological behavior of the essential trace element Potassium rather than on its intake (Akinloye and Olomo, 2000; Jibiri and Ajao, 2005), hence the dose from ${ }^{226} \mathrm{Ra}$ and ${ }^{232} \mathrm{Th}$ are only considered as they are known to contribute between $40 \%$ and $60 \%$ respectively of the internal dose resulting from food product intake. The results of the calculation are also presented in Table III. The total estimated annual 
TABLE V

The mean annual consumption (MAC) values per kilogram per person. Consommation annuelle moyenne par kg et par personne.

\begin{tabular}{lc}
\hline Food Type & MAC kg/Person ${ }^{\S}$ \\
\hline Maize & 20.67 \\
Millet & 36.24 \\
Rice & 26.35 \\
Guinea corn & 44.70 \\
Other cereals & 0.60 \\
Cassava & 115.46 \\
Sweet potatoes & 14.35 \\
Yam & 75.15 \\
Other roots & 6.50 \\
Wheat & 18.55 \\
Beans & 0.02 \\
\hline \& Data was collected from the Federal Office of Statistics(FOS), Nigeria/FAO 2006.
\end{tabular}

dose due to intake of the food crops ranged between 0.01 (Acha) and $1.35 \mathrm{mSv} \mathrm{y}^{-1}$ (Cassava) with a cumulative total dose estimated as $2.5 \mathrm{mSv} \mathrm{y}^{-1}$. Although not all crops were sampled such as rice though not grown in the area, the total effective dose estimated in this study is seen to represent a reasonable range due to intakes in the area. Nevertheless, it represents a useful small database that will allow more thorough investigations in future works in the area. The small database is also seen to be useful to the newly established Nigerian Nuclear Regulatory Authority (NNRA) in their food policy, administration and regulatory functions.

\section{Conclusion}

The major, trace elements and natural radionuclide concentrations have been determined in crops of important nutritive requirements in an old tin mining area in Bitsichi town in Jos-plateau, Nigeria. The major trace elements $\mathrm{Na}, \mathrm{K}, \mathrm{Mg}, \mathrm{Cl}$ were detected in all the food crops except $\mathrm{Ca}$ that was below detection in the cereal crops. The real trace elements Sc, Hf, Sm and Th were all below detection in the crops except in Green beans. Rubidium ( $\mathrm{Rb}$ ) and lanthanum (La) were found to be below detection limits only in Cabbage. The activity concentrations of the natural radionuclides in the food samples was found to vary between $83 \mathrm{~Bq} \mathrm{~kg}^{-1}$ in sweet potato and $129 \mathrm{~Bq} \mathrm{~kg}^{-1}$ in cassava for ${ }^{40} \mathrm{~K}, 19 \mathrm{~Bq} \mathrm{~kg}^{-1}$ in cassava and $30 \mathrm{~Bq} \mathrm{~kg}^{-1}$ in acha for ${ }^{226} \mathrm{Ra}$ while $27 \mathrm{~Bq} \mathrm{~kg}^{-1}$ in acha and $41 \mathrm{~Bq} \mathrm{~kg}^{-1}$ in sweet potato for ${ }^{232} \mathrm{Th}$. The activity concentrations of ${ }^{40} \mathrm{~K},{ }^{226} \mathrm{Ra}$ and ${ }^{232} \mathrm{Th}$ in the food crops from this area were found to be higher than those obtained in other parts of the country 
and in the similar crops from the control site. The total estimated annual dose due to intake of the food crops ranged between 0.01 (Acha) and $1.35 \mathrm{mSv} \mathrm{y}^{-1}$ (Cassava) with a cumulative total dose estimated as $2.5 \mathrm{mSv} \mathrm{y}^{-1}$. The mining activities in the area are seen to have influenced the concentration of these trace elements and radionuclides in the food crops. However, they are seen not to pose any serious internal health burden due to ingestion given the realities of food choice by individuals in the study area.

Acknowledgement. We are grateful to International Foundation for Science (IFS), Sweden for providing the research grant used in carrying out this study. We are also grateful to the Centre for Energy Research and Training (CERT) Ahmadu Bello University Zaria, Nigeria, for the access to the research reactor and the gamma spectrometer.

\section{REFERENCES}

Akinloye M.K., Olomo J.B. (2000) The measurement of the natural radioactivity in some tubers cultivated in farmlands within the Obafemi Awolowo University Ile-Ife, Nigeria, Nig. J. Phys. 12, 60-63.

Alexander M.J. (1996) The effectiveness of small scale irrigated agriculture in the reclamation of mine land soils on the Jos Plateau Nigeria, Land Degrad. Develop. 7, 77-85.

Alexander M.J., Kidd A.D. (2000) Farmer's capability and institutional incapacity in Reclaiming disturbed land on the Jos Plateau, Nigeria, J. Environm. Managem. 59, 141-155.

Arogunjo A.M (2003) Natural radionuclides content of some local cereals in Akure, Southwestern Nigeria, Nig. J. Pure Appl. Phys 2, 34-35.

Babalola I.A. (1984) Radiation measurement and assay of tailing from high natural radioactivity in Plateau State, Nig. J. Sci. 18, 98-101.

Badejoko T. (1975) Evidence of migmatite differentiation in the young granites of Nigeria, Nig. J. Mining Geol. 10, 42-67.

Breuninger M.I., Schachtel G.A., Luhraman P.M., Hartmann B., Neuhauser-Berthold M. (2002) Complex correlation structure in consumption rates of major food group: Implications for the assessment of radiation exposure, Public Health Nutr. 6, 87-94.

Farai I.P., Sanni A.O. (1992) ${ }^{222} \mathrm{Rn}$ in a groundwater in Nigeria: A Survey, Health Phys. 62, 96-98.

Farai I.P., Jibiri N.N. (2000) Baseline studies of terrestrial outdoor gamma dose rate evels in Nigeria, Rad. Prot. Dosim. 88, 247-250.

Hernandez F., Hernandez-Armas J., Catalan A., Fernandez-Aldecoa J.C., Landeras M.I. (2004) Activity concentrations and mean effective dose of foodstuffs on the Island of Tenerife, Spain, Rad. Prot. Dosim. 111, 205-210.

ICRP Publication 72 (1996) Age-dependent doses to members of the public from intake of radionuclides: Part 5. Compilations of Ingestion and inhalation dose coefficients. Pergamon Press, Oxford

Jibiri N.N., Ajao A.O. (2005) Natural activities of ${ }^{40} \mathrm{~K},{ }^{238} \mathrm{U}$ and ${ }^{232} \mathrm{Th}$ in Elephant grass (pennisetum purpureum) in Ibadan, Metropolis Nigeria, J. Environ. Radioact. 78, 105-111.

Jibiri N.N., Bankole O.S. (2006) Soil radioactivity and radiation absorbed dose rates at roadsides in high-traffic density area in Ibadan Metropolis, southwestern, Nigeria, Rad. Prot. Dosim. 118, 453-458. 
Maziya-Dixon B., Akinyele I.O., Oguntona E.B., Sanusi R.A., Harris E. (2004) Nigeria food consumption and nutrition survey 2001-2003 (Summary), Publication of the International Institute of Tropical Agriculture (IITA), Ibadan, Nigeria, Nigeria Food Survey 1, 1-75.

Mc Donald P., Jackson D., Leonard D.R.P., Mc Kay K. (1999) An assessment of ${ }^{210} \mathrm{~Pb}$ and ${ }^{210} \mathrm{Po}$ terrestrial foodstuffs from regions of potential technological enhancement in England and Wales, J. Environ. Radioact. 43, 15-29.

Njafang N., Matschullat M., Tchouankoue T. (2006) Trace elements in soils and plants of the noun valley, western Cameroon: a contribution to the development of a baseline biogeochemical database, Geophys. Res. Abstr. 8, 0760.

Olayemi J.K (1998) Food security in Nigeria. Research report No 2- series of Development Policy Center Agodi Ibadan Nigeria.

Olomo J.B. (1990) The natural radioactivity in some Nigerian foodstuffs, Nucl. Instrum. Meth. A 299, 666-669.

Oresegun M.O., Babalola I.A. (1990) Occupational radiation exposure associated with milling of Th-U rich Sn in Nigeria, Health Phys. 58, 213-215.

Oresegun M.O., Babalola I.A. (1993) The environmental gamma radiation level of Jos, Nigeria, Nig. J. Sci. 27, 263-268.

Pasquini M.W., Alexander M.J. (2005) Soil fertility management strategies on the Jos Plateau: the need for integrating empirical and scientific knowledge in agricultural development, Geograph. J. 171, 112-124.

RIFE (2005) Radioactivity in Food and the Environment, The Center for Environment, Fisheries and Aquaculture science (CEFAS), Radioactivity in food and the environment, 2004 report RIFE10. 